cannot definitely be recommended despite the carrot of a more physiological action profile. Apart from the practical problems of assessing the depth of subcutaneous tissue in a large number of patients - and the provision of a range of needle lengths-longer term studies are needed on blood glucose control, the relative rate of hypoglycaemia, effects of exercise, and patient acceptability. Until such data are available it may perhaps be wise to recommend that soluble insulin is also injected at an angle into a skin fold or to provide shorter needles of 3-5 mm.

JONATHAN THOW Clinical Research Fellow PHILIP HOME

Consultant Physician and Senior Lecturer

Freeman Hospital,

University of Newcastle upon Tyne,

Newcastle upon Tyne NE7 7DN
1 Watkins PJ. Insulin treatment. Br Med f 1982;284: 1929-32.

Frid A, Linden B. Where do lean diabetics inject their insulin? A study using computed omography. Br. Med f 1986:292:1638.

Frid A, Gunnarsson R, Guntner P, Linde B. Effects of accidental intramuscular injection on insulin absorption in IDDM. Diabetes Care 1988;11:41-5.

Spraul M, Chantelau E, Koumoulidou J, Berger M. Subcutaneous or nonsubcutaneous injection of insulin. Diabetes Care 1988;11:733-6.

6 Owens DR, Hayes TM, Alberti KGMM, et al. Comparative study of subcutaneous, intramuscula and intravenous admirristration of human insulin. Lancet 1981; ii:118-21.

Shahshahani $M$, Kitabchi A. Glucose lowering effect of insulin by different routes in obese and lean nonketotic diabetic patients. F Clin Endocrinol Metab 1978;47:34-40.

8 Micossi $M$, Cristallo $M$, Librenti $M$, et al. Free insulin profiles after intraperitoneal, intramuscula and subcutaneous insulin administration. Diabetes Care 1986;9:575-8.

9 Galloway J, Spradlin C, Nelson R, Wentworth S, Davidson J, Swarner J. Factors influencing the absorption, serum insulin concentration, and blood glucose responses after injections of regula and various insulin mixtures. Diabetes Care 1981:4:366-76.

10 Vaag A, Damgaard Pedersen K, Lauritzen M, Hildebrandt P, Beck-Nielsen H. Intramuscular versus subcutaneous injection of unmodified insulin. Consequences for blood glucose control in patients with Type 1 diabetes mellitus. Diabetic Med 1990;7:335-42.

11 Lauritzen T, Pramming S, Gale EAM, Deckert T, Binder C. Absorption of isophane (NPH) insulin and its clinical implications. Br Med 7 1982;285:159-62.

12 Vaag A, Handberg A, Lauritzen M, et al. Variation in absorption of NPH insulin due to intramuscular injection. Diabetes Care 1990;13:74-6.

13 Francis $A$, Home $P$, Walford $S$, et al. Prevalence of morning hyperglycaemia: determinants of fasting blood glucose concentrations in insulin-treated diabetics. Diabetic Med 1985;2:89-94.

\title{
Emergency treatment of avulsed incisor teeth
}

\author{
Is simple but it needs to be prompt
}

The fall in the prevalence of dental caries in the past decade has been mirrored by an increase in the number of children and young adults with injuries to their teeth. ${ }^{1} \mathrm{~A}$ greater understanding of the factors affecting the prognosis after dental injuries, together with improvements in restorative materials and techniques, has led to many teeth being saved that once would have been lost. In the case of completely avulsed teeth, however, prompt action is needed to preserve and reposition a tooth if it is to be successfully reimplanted. ${ }^{2}$ This task often falls to casualty officers.

An avulsed tooth should be replanted within its socket as soon as possible and then stabilised until the gingival and periodontal tissues can be repaired. After an hour outside the socket a tooth that has been allowed to get dry has a poor chance of successful reimplantation because the cells on the root surface that are necessary for reattachment start to die. If immediate reimplantation is not possible the prognosis can be improved by careful storage. For up to an hour the vitality of the cement can be maintained by wrapping the tooth in plastic foil. ${ }^{3}$ For longer than that cell viability can be sustained by storing the tooth in milk, which has an osmolarity and $\mathrm{pH}$ $(230-270 \mathrm{mmol} / \mathrm{kg}$ and 6.6$)$ compatible with cell survival. ${ }^{4}$

Reimplantation is carried out by rinsing the tooth gently in saline and placing it in the socket, taking care to handle it by the crown. Gentle pressure will allow the tooth to be seated in the socket without pain. If shown how, many children will replant the tooth themselves. Temporary stabilisation with aluminium foil or with histoacryl tissue adhesive, as described by $\mathrm{McCabe}$ on $\mathrm{p} 20$, will hold the tooth in place until definitive dental treatment can be given. Avulsed teeth need to remain splinted for about 14-21 days.

The major cause of tooth loss after reimplantation is resorption of the tooth root accompanied by inflammation or ankylosis. The tooth socket wall is continually being remodelled in response to functional demands, and the cement on the root surface tends to thicken with age. After avulsion pathological resorption often occurs on the root surface, the cement being replaced by granulation tissue or bone. Under ideal conditions, when injury to the root surface is minimal, repair of the periodontal membrane may occur within 14 days. The state of the pulp is also critical in root resorption, and in young children whose roots are not fully developed early replantation enables the pulp to recover.

The prognosis is improved by using ampicillin after replantation as control of bacterial invasion into the injured tissues will prevent inflammatory resorption. ${ }^{5}$ Gingival healing is also important, so $2 \%$ chlorhexidine mouth rinse should be used twice or three times daily to reduce the accumulation of plaque. The patient may also need an antitetanus toxoid booster, particularly if the injury occurred out of doors. Finally, the patient, with his or her replanted and stabilised tooth, should be referred to a dentist for further care as soon as possible.

\section{BARRY SCHEER}

Lecturer in Paediatric Dentistry,

Department of Child Dental Health,

London Hospital Medical College,

London E1 2AD

1 Todd JE, Dodd T, for the Office of Population Cencuses and Survevs, Social Survey Division Children's dental health in the UK 1983. London: HMSO, 1985.

2 Hammarstrom L, Pierce A, Blomlof L, Feiglin B, Lindskog S. Tooth avulsion and replantationreview. Endodontics and Dental Traumatology 1986;2:1-8.

3 Blomlof L, Lindskog S, Andersson L, Hedstrom K.G, Hammarstrom L. Periodontal healing of replanted monkey teeth prevented from drying. Acta Odontol Scand 1983;41:117-23.

4 Blomlof L. Milk and saliva as possible storage media for traumatically exarticulated teeth prior to replantation. Swed Dental f 1981; suppl 8:1-26.

Hammarstrom L, Blomlof L, Feiglin B, Andersson L, Lindskog S. Replantation of teeth and antibiotic treatment. Endodontics and Dental Traumatology 1986;2:51-7.

\section{Correction}

\section{Late onset asthma}

A printer's error occurred in this editorial by $\mathrm{Mr}$ Jon $\mathrm{G}$ Ayres (23 June, $\mathrm{p}$ 1602). In the eighth line of the fifth paragraph the drugs referred to are $\beta$ blockers and not $\mathrm{Hgb}$ blockers as published. 